\section{Evaluation of Some Immunological and Haematological Indices of Hepatitis B Infected Subjects in Nnamdi Azikiwe University Teaching Hospital, Nnewi, Anambra State, Nigeria}

\section{Abstract}

This study was carried out to evaluate some immunological and haematological indices of HBV infected subjects in Nnamdi Azikiwe University Teaching Hospital, Nnewi. A total of 150 blood samples were collected from confirmed HBV positive subjects that have tested negative to HIV and HCV and consisted of (65 males) and ( 85 females) with average age of 35 years. A 102 apparently healthy subjects (controls), consisted of ( 58 males) and ( 44 females) with average age of 35 years. The investigations for positive and control subjects were done using standard methods. Haematological parameters were assessed using Sysmex KX-21 N automated counter. CD4 was estimated using Partec CD4 easy count kit with Partec IVD Flow Cytometer. IgG and IgM levels were determined using quantitative turbidmetric method at 540 and $340 \mathrm{~nm}$. Serological markers: $\mathrm{HBsAg}$, $\mathrm{HBeAg}, \mathrm{HBsAb}, \mathrm{HBeAb}$ and $\mathrm{HBcAb}$ were determined using one step cassette $\mathrm{HBV}$ test kit. Results revealed that there was significant difference between the haemoglobin concentration, monocytes and packed cell volume of hepatitis $B$ infected subjects of different age group $(P<0.05)$. The IgM of the positive subjects was significantly lower than that of the control negative subjects $(P<0.05)$. The IgM of the $\mathrm{HbAg}$ positive markers was significantly lower than that of the control negative counterpart likewise the female subjects $(P<0.05)$. The CD4 count, absolute eosinophils count and monocytes count of $\mathrm{HbsAg}$ positive subjects were significantly lower than that of the $\mathrm{HbAg}$ negative subjects $(P<0.05)$. The absolute eosinophils count of $\mathrm{HbAg}$ positive males was significantly lower than that of the control negative subjects $(P<0.05)$. We also discovered that the CD4 count, absolute lymphocyte count and monocytes counts were significantly lower in $\mathrm{HbAg}$ positive females than their control counterpart $(P<0.05)$. The haemoglobin concentration, eosinophils count and monocytes count of the $\mathrm{HbAg}$ positive subjects was significantly lower than that of the control counterparts. It also revealed high prevalence markers of $\mathrm{HBV}$ in the study population as, $\mathrm{HBsAg}$ (88\%) , HBeAg (30.7\%), HBsAb (4.0\%), HBeAb (8.0\%), HBcAb (13.3\%) and high prevalence $\mathrm{HBCAb}(54.9 \%)$ markers in control negative subjects $(P<0.05)$. The importance of proper evaluation using all hepatitis $B$ markers for immunological and haematological diagnosis of hepatitis B virus infection cannot be neglected. The result of this study shows the need to include all the serological markers, immunological and haematological parameters in routine diagnosis of HBV infection in Nigeria. It also confirms the fact that testing blood donors for HBsAg alone is not sufficient to eliminate HBV from blood.

Keywords: Immunological; Haematological indices; Hepatitis B Infected subjects; Nnamdi Azikiwe University Teaching Hospital; Nnewi
Onwuasoanya Uche

Francisca ${ }^{1}$,

lhonglbe J $\mathrm{C}^{2}$,

Obeagu Emmanuel Ifeanyi ${ }^{3}$, Ifeanyichukwu Martin $\mathrm{O}^{1}$, Nwachukwu Patience Ebele ${ }^{4}$ and

\section{Ochiabuto Ogochukwu MTB ${ }^{1}$}

1 Department of Medical Laboratory Science, Nnamdi Azikiwe University, Nnewi Campus, Anambra State, Nigeria

2 Department of Medical Laboratory Science, Babcock University, Ilisan Remo, Ogun State, Nigeria

3 Diagnostic Laboratory Unit, Department of University Health Services, Michael Okpara University of Agriculture, Umudike, Abia State, Nigeria

4 Department of Chemical Pathology, Nnamdi Azikiwe University, Nnewi Campus, Anambra State, Nigeria

Corresponding author:

Obeagu Emmanuel Ifeanyi

झ emmanuelobeagu@yahoo.com

Diagnostic Laboratory Unit, Department of University Health Services, Michael Okpara University of Agriculture, Umudike, Abia State, Nigeria.

Tel: +2348037369912

Citation: Francisca OU, Ihongbe JC, Ifeanyi $\mathrm{OE}$, et al. Evaluation of Some Immunological and Haematological Indices of Hepatitis B Infected Subjects in Nnamdi Azikiwe University Teaching Hospital, Nnewi, Anambra State, Nigeria. J Biomedical Sci. 2017, 6:3. 


\section{Introduction}

Hepatitis is the inflammation of the liver. It could be caused by a variety of agents such as viruses, bacteria, toxic agents, or drugs, metabolic and circulatory disorders or from autoimmune disorders [1]. Hepatitis B virus stems from the family Hepadnaviridae, genus-hepadnavirus and species hepatitis B virus [2]. The virus was discovered in 1963 by Baruch Blumberg. He discovered the Australian antigen (later known as hepatitis $B$ surface antigen) in the blood of Australian Aboriginal people [3]. It is a double stranded circular DNA virus composed of an outer envelope containing hepatitis $B$ surface antigen $(\mathrm{HBsAg})$ and an inner nucleocapsid consisting of hepatitis $B$ envelope antigen ( $\mathrm{HBeAg})$ and hepatitis $B$ core antigen $(\mathrm{HBcAg})$. Corresponding antibodies to each of these antigens are - Hepatitis $B$ surface antibody (HBsAb), Hepatitis $B$ envelope antibody ( $H B e A b)$ and Hepatitis B core IgM and IgG antibody (anti $\mathrm{HBc}$ or $\mathrm{HBc} A b$ ). The viral core also contains double stranded DNA genome and DNA polymerase $[4,5]$.

The serological markers of $\mathrm{HBV}$ are; $\mathrm{HBsAg}, \mathrm{HBsAb}, \mathrm{HBeAg}$, $\mathrm{HBeAb}, \mathrm{HBCAg}$ and HBcAb or $\mathrm{HBC}$ (IgM and IgG), and Hepatitis $B$ virus DNA; these are important as they can be used in the diagnosis of the infection and to determine the severity of the infection $[6,7]$.

Hepatitis B virus infects the liver of hominoidea, including humans and causes an inflammation called hepatitis, originally known as serum hepatitis [8]. Hepatitis B virus causes liver diseases that vary greatly in severity from person to person [9]. Some subjects control infection efficiently and clear the virus from the blood stream either without clinically evident liver disease or with an acute inflammation of the liver (acute hepatitis) that can resolve without long-term clinical sequelea. Other patients fail to clear the virus and develop chronic infection.

Most chronically infected patients remain largely asymptomatic without life-threatening liver disease but $10-30 \%$ develops liver cirrhosis with possible progression to liver cancer $[7,10]$. The rate of HBV chronicity is low in adult infections ( $5 \%$ or lower) but age and route of infection influence the outcome with exposure in neonatal life leading to a high rate of HBV persistence $[9,10]$. The progression to chronicity and complication is directly related to high viral replication demonstrable serologically by the presence of markers of pathogenicity and infectivity [11]. These serological markers include Hepatitis B surface antigen ( $\mathrm{HBsAg}$ ), $\mathrm{HB}$ anticore antibody (anti $\mathrm{HBclgM}$ and $\mathrm{HBclgG}$ ), Hepatitis e antigen ( $\mathrm{HBeAg}$ ), antihepatitis e antibody (anti HBeAb), and HBV DNA [12]). Hepatitis $B$ ' $e$ ' antigen reflects high viral replication and infectivity $[13,14]$. An estimated number of 600,000 people die every year related to hepatitis $B$ virus infection [15].

Diagnosis of HBV in Nigeria is still at an embryonic stage. Most health care provided, relied immensely on rapid diagnostics which detect only HBsAg. Several studies have shown HBsAg markers, are not specific for HBV infection diagnosis. Other markers for correct diagnosis which are not usually determined in Nigeria are necessary in confirming diagnosis. The need for proper diagnosis using these other makers cannot be over emphasized. In other words, the immunological and haematological status of HBV patients is seriously neglected. It is true that the prevalence is low, but Hepatitis B infects at least $5 \%$ of the world's population and is the ninth leading cause of death worldwide [1].

Hence, limiting the spread of HBV a silent killer ranges from adequate control measures such as the use of vaccine that has an outstanding record of safety and efficacy in preventing development of the chronic carrier state [16] to routine vaccination of newborns which should be available in low resource setting in Nigeria. Even though Nigeria approved the inclusion of hepatitis B vaccine in its National program on Immunization (NPI) in 1995, the vaccine only become widely available in 2004 [17]. Despite the fact that the vaccine had been made available via the NPI, Immunization coverage for Hepatitis B is still not optimal in low resource settings in Nigeria [17]. A recent study in Nigeria showed that the Hepatitis $B$ vaccine coverage rate in low resources settings is currently about $41 \%$ [18]. The consequences of $\mathrm{HBV}$ infection due to poor screening and low vaccination rate are that of vertical transmission of hepatitis B virus which has become the major route of transmission of the virus in Nigeria. Shi, et al. [19] showed that besides the WHO recommended joint immunoprophylaxis starting from the newborn, multiple injections of small doses of hepatitis $B$ immunoglobulin ( $\mathrm{HBI}$, 200-400 1 u per month) or oral Lamivudine (100 mg per day) in HBV carrier mothers with a high degree of infectiousness (>106 copies $/ \mathrm{ml}$ ) in late pregnancy effectively and safely prevent HBV intrauterine transmission, which provide new insight into preventing HBV at the earliest stage $[19,20]$.

\section{Aim}

The overall aim of the study is therefore designed to elucidate some immunological and haematological responses in $\mathrm{HBV}$ infection and determine the effective methods of controlling the infection process.

\section{Materials and Methods}

\section{Area of study}

This study was carried out in Nnamdi Azikiwe University Teaching Hospital, located in Nnewi North Local Government, Anambra state, which lies between longitude $6.9^{\circ} \mathrm{E}$ and Latitude $6.02^{\circ}$ with a population of 193,987 according to the [21].

\section{Ethical permission}

Ethical permission was obtained from the ethical committee of Nnamdi Azikiwe University Teaching Hospital, located in Nnewi North Local Government area, Anambra State.

\section{Sample size/selection}

A total number of 252 participants were recruited in this study. Blood samples were collected from confirmed $150 \mathrm{HBV}$ positive subjects that have tested HIV and HCV negative that consists of (65 males), (85 females) and same blood sample from 102 apparently healthy subjects (as control) consisted of (58 males) and (44 females) [22]. 


\section{Sample collection}

Samples were collected in EDTA and plain tubes. A total of 6 $\mathrm{ml}$ of venous blood was collected from confirmed HBV positive individuals and same $6 \mathrm{ml}$ of blood from control subjects. Two $\mathrm{ml}$ of the blood from each patient was dispensed into an EDTA container and was used for full blood count, HIV and CD4 count. The other $4 \mathrm{ml}$ in plain container was allowed to retract and the serum separated from the cells after centrifugation. Some of the sera was used for HBV, HCV screening and the remaining sera kept frozen in a deep freezer at $20^{\circ} \mathrm{C}$ and were used for IgG and IgM analysis.

\section{Method of Investigation}

Haematological parameters (differential white blood cells and total white blood cells) were assessed using Sysmex KS-21 N automated counter. The CD4 was estimated using Partec CD4 easy count kit with Partec IVD Flow Cytometer. (Partec GrmbH AM flugplatz 13.D - 02828 Gorlitz. Germany). IgG and IgM levels were determined using quantitative turbidmetric method (Linear chemicals SL Montgat, Barcelona, Spain). Serological Markers: $\mathrm{HBsAg}, \mathrm{HBeAg}, \mathrm{HBsAb}, \mathrm{HBeAb}$ and $\mathrm{HBcAb}$ were screened using immunochromatographic method (Linear chemicals SL Montgat, Barcelona, Spain).

\section{Haematological Parameters}

The hematological parameters of the subjects (differential white blood cells and total white blood cells) were assessed using the Sysmex KX-21 N automated counter (Stockholm, Sweden). The tests were done according to the instruction of the automatic multiparameter blood counter.

\section{Measurement of Total Serum IgM}

\section{Assay procedure}

The reagent and photometer (cuvette holder) were prewarmed to $37^{\circ} \mathrm{C}$. Distilled water was used to zero the instrument at 340 $\mathrm{nm}$. Ten $\mu \mathrm{l}$ of sample calibrator was pipetted into a cuvette, 1.0 $\mathrm{ml}$ of reagent (R1) was also added to cuvette and it was well mixed. The cuvette was inserted into the spectrophotometer. The absorbance (a) was recorded after 2 minutes of the sample addition.

Each run included a set of control with assayed values handled as unknowns to ensure adequate quality control.

\section{Measurement of Total Serum IgG}

\section{Serological markers}

HBsAg, HBeAg, HBsAb, HBeAb and HBcAb were determined using one step cassette style HBV test device, which is a rapid test based on the principle of immunoassay combined with conjugated colloid technology (Linear-chemicals SL Montgat, Barcelona, Spain).

\section{One Step Hepatitis C Virus Serum/ Plasma Test}

\section{Procedure}

The test strip and specimen were brought to room temperature $\left(180^{\circ} \mathrm{C}-300^{\circ} \mathrm{C}\right)$. Test strip was removed from the foil pounch and placed on a level surface. The test strip was immersed into the specimen with the arrow pointing towards the specimen and it was removed after 10 seconds and layed flat on a clean dry surface. The result was read after 15 minutes. Rose pink bands in both the control and test region indicates a positive result for $\mathrm{HCV}$ antibodies in the test region, but only in the control region indicates a negative result.

\section{HIV screening}

Stat pak HIV 1 and 2 rapid test kit by immunochromatography was used.

\section{Results}

Mentioned in Tables 1-10.

\section{Discussion}

This study has demonstrated a varying percentage of detection rates of $\mathrm{HBV}$ markers (HBsAg 88\%, HBeAg 30.7\%, HBcAb $13.3 \%$, $\mathrm{HBeAb} 8.0 \%$, and $\mathrm{HBsAb} 4.0 \%$ ) with the highest rate for $\mathrm{HBsAg}$ $(88 \%)$ in subjects with exposure to HBV infection. The result is similar to earlier observation reported among Nigerian patients with acute hepatitis and chronic hepatitis by $[23,24]$ Ola, et al. [23-25] documented $89 \%$ prevalence rate of $\mathrm{HBsAg}$ while this present work shows $88 \%$ and this suggests the need for correct diagnosis of patients with HBV infection. The detection of other markers among both HBsAg sero-postive and sero-negative Nigerians is significant.

This study also reveals high prevalence of antihepatitis B core antibody (HBcAb) in both positive (13.3\%) HBV subjects and

Table 1 Comparison of the mean \pm SD of haematological parameters of HBAg positive subjects according to their age groups.

\begin{tabular}{|c|c|c|c|c|c|c|c|c|}
\hline Age (years) & $\mathrm{Hb}(\mathrm{g} / \mathrm{dL})$ & PCV (L/L) & WBC $\left(\times 10^{9} / L\right)$ & $\begin{array}{c}\text { Neut } \\
(\%)\end{array}$ & Lymph (\%) & $\begin{array}{c}\text { Eosin } \\
(\%)\end{array}$ & $\begin{array}{c}\text { Baso } \\
\text { (\%) }\end{array}$ & Mono (\%) \\
\hline $15-25(n=50)$ & $11.7 \pm 1.6$ & $36.7 \pm 6.6$ & $4.84 \pm 1.34$ & $49.4 \pm 10.3$ & $45.7 \pm 10.4$ & $1.9 \pm 1.3$ & $1.8 \pm 1.7$ & $1.2 \pm 1.4$ \\
\hline $26-35(n=54)$ & $12.1 \pm 1.5$ & $38.9 \pm 5.9$ & $4.48 \pm 1.13$ & $48.1 \pm 9.2$ & $46.9 \pm 9.6$ & $2.4 \pm 2.1$ & $1.5 \pm 1.6$ & $1.1 \pm 1.3$ \\
\hline $36-45(n=28)$ & $11.9 \pm 1.5$ & $37.8 \pm 4.5$ & $4.81 \pm 1.26$ & $48.9 \pm 5.9$ & $45.4 \pm 7.5$ & $2.4 \pm 1.8$ & $2.1 \pm 1.5$ & $1.2 \pm 1.5$ \\
\hline $46-55(n=18)$ & $13.1 \pm 1.7$ & $42.4 \pm 7.5$ & $4.64 \pm 1.57$ & $46.0 \pm 9.6$ & $49.8 \pm 10.1$ & $2.1 \pm 1.8$ & $1.7 \pm 1.6$ & $0.4 \pm 0.5$ \\
\hline $\mathbf{F}$ & 3.574 & 4.199 & 0.837 & 0.677 & 0.985 & 0.79 & 0.84 & 4.253 \\
\hline P-value & $0.016^{*}$ & $0.007^{*}$ & 0.476 & 0.568 & 0.401 & 0.501 & 0.474 & $0.007^{*}$ \\
\hline
\end{tabular}

$* P<0.05$ (Significant) 
Table 2 IgG and IgM of HBAg positive subjects compared with the HBAg control negative subjects.

\begin{tabular}{|l|c|c|c|c|} 
& $\begin{array}{c}\text { HbAg Positive } \\
(\mathbf{n = 1 0 2})\end{array}$ & $\begin{array}{c}\text { HbAg } \\
\text { Negative( } n=102)\end{array}$ & t-value & P-value \\
\hline IgG (mg/dL) & $2282.9 \pm 494.9$ & $2314.5 \pm 401.4$ & -0.482 & 0.631 \\
\hline IgM (mg/dL) & $272.4 \pm 97.6$ & $489.8 \pm 120.7$ & -13.979 & $0.000^{*}$ \\
\hline
\end{tabular}

$* P<0.05$ (Significant)

Table 3 IgG and IgM of male HBAg positive subjects compared with the male HBAg control negative subjects.

\begin{tabular}{|c|c|c|c|c|}
\hline & $\begin{array}{c}\text { HbAg Positive } \\
(\mathbf{n}=58)\end{array}$ & $\begin{array}{c}\text { HbAg Negative } \\
(\mathbf{n}=58)\end{array}$ & t-value & P-value \\
\hline IgG (mg/dL) & $2247.4 \pm 459.8$ & $2343.8 \pm 438.5$ & -1.123 & 0.266 \\
\hline IgM (mg/dL) & $283.5 \pm 89.8$ & $505.4 \pm 133.6$ & -12.109 & $0.004^{*}$ \\
\hline
\end{tabular}

$* P<0.05$ (Significant)

Table 4 IgG and IgM of female HBAg positive subjects compared with the female HBAg control negative subjects.

\begin{tabular}{|l|c|c|c|c|} 
& $\begin{array}{c}\text { HbAg Positive } \\
(\mathbf{n}=44)\end{array}$ & $\begin{array}{c}\text { HbAg Negative } \\
(\mathbf{n}=44)\end{array}$ & t-value & P-value \\
\hline IgG (mg/dL) & $2343.0 \pm 536.1$ & $2276.0 \pm 342.1$ & 0.76 & 0.452 \\
\hline IgM (mg/dL) & $270.3 \pm 88.8$ & $469.2 \pm 99.0$ & 1.207 & $0.000^{*}$ \\
\hline
\end{tabular}

$* P<0.05$ (Significant)

Table 5 CD4 and absolute leucocyte counts (Neutrophil, lymphocyte, eosinophil, basophil, monocyte) of HBAg positive subjects compared with the HBAg control negative subjects.

\begin{tabular}{|c|c|c|c|c|}
\hline & $\begin{array}{l}\text { HbAg Positive } \\
\text { (n=102) }\end{array}$ & $\begin{array}{l}\text { HbAg Negative } \\
\quad(n=102)\end{array}$ & t-value & P-value \\
\hline $\begin{array}{l}\text { CD4 count } \\
\text { (cells } / \mu \mathrm{L} \text { ) }\end{array}$ & $1087.42 \pm 499.77$ & $1280.45 \pm 351.26$ & -3.081 & $0.003 *$ \\
\hline $\begin{array}{l}\text { Abs. Neut } \\
\left(\times 10^{9} / \mathrm{L}\right)\end{array}$ & $2.45 \pm 1.48$ & $2.35 \pm 0.71$ & 0.599 & 0.551 \\
\hline $\begin{array}{c}\text { Abs. Lymph } \\
\left(\times 10^{9} / \mathrm{L}\right)\end{array}$ & $2.13 \pm 0.67$ & $2.21 \pm 0.77$ & -0.639 & 0.524 \\
\hline $\begin{array}{l}\text { Abs. Eosin } \\
\left(\times 10^{9} / \mathrm{L}\right)\end{array}$ & $0.11 \pm 0.09$ & $0.14 \pm 0.15$ & -1.982 & $0.050 *$ \\
\hline $\begin{array}{l}\text { Abs. Baso } \\
\left(\times 10^{9} / \mathrm{L}\right)\end{array}$ & $0.09 \pm 0.08$ & $0.08 \pm 0.09$ & -0.091 & 0.928 \\
\hline $\begin{array}{c}\text { Abs. Mono } \\
\left(\times 10^{9} / \mathrm{L}\right)\end{array}$ & $0.09 \pm 0.10$ & $0.06 \pm 0.07$ & 2.072 & $0.041 *$ \\
\hline
\end{tabular}

$* \mathrm{P}<0.05$ (significant)

negative (54.9\%) control subjects and it also suggests need for correct diagnosis of patients with HBV infection because the antigen ( $\mathrm{HBCAg}$ ) is a marker of the infectious viral replication. This also shows much acute infection because the antibody is produced during and after an acute HBV infection. Consequently, anti-HBc is considered to be a more specific marker for HBV infection during window period and it indicates incidence of post hepatitis B amongst the control and positive subjects [26].

The statistical difference in haemoglobin concentration, packed cell volume and monocyte of HBV positive subject when compared according to their age range $(P<0.05)$ is in line with work done by Fasola, et al. [27] in Haematological parameters of Nigerians with acute viral Hepatitis. Packed cell volume in most patients with acute viral hepatitis gradually decreases during the first three weeks of illness [28]. The PCV and HB level of patients in the age range of $15-25,26-35$, and $36-45$ were low compare to PVC and HB level of age range 46-55 could be attributed to feeding style or a temporary bone marrow suppression and autoimmune haemolytic anaemia which may accompany viral hepatitis. Monocytosis agrees with the work of Vingerhoets, et al. [29] that blood monocytes increases in viral infection.

Significant difference existed $(P<0.05)$ in absolute leucocytes count (Eosinophil) for HBV positive male subjects when compared with negative control group, but eosinophils and basophils has no value in viral infection. There was significant difference in mean \pm SD of absolute leucocyte count (monocyte) in haematological parameters of female HBV positive subjects when compared with female control subjects $(P<0.05)$ was also attributed to the fact that monocytes increases during viral hepatitis.

Statistical difference was observed in patients haemoglobin concentration, eosinophils and monocyte with $(P<0.05)$ when compared with haemoglobin concentration, eosinophils and monocytes of negative control subjects. The present study is in agreement with Zuberi, et al. who illustrated in a study done for HBV in immunoglobulin liver disease that lymphocytes will increase in viral infection due to activation of lymphocyte proliferation, while monocytosis occur as a result of chronic infection and decrease in neutrophils number due to increment in lymphocytes number upon computation of neutrophils, while the eosinophils and basophils have no value in viral infection [30]. Vingerhoets, et al. [29], found that the peripheral blood monocytes increase in viral infection. Another study was done for patients with chronic HBV and showed that the lymphocytes will increase while the neutrophils will decrease and no changes in total leucocytes count [31].

In this study it was found that the mean values of serum IgG for positive subjects was lower than in control negative subjects. Explanation of these results is that IgG was not elevated because the patients has not developed chronic HBV they have less severe inflammation and IgG values comparable to normal [32]. Anti$\mathrm{HBC}$ IgG may remain positive for life in an infected individual, although the individual has protective levels of anti-HBs and therefore does not necessarily mean that blood of such person is infectious.

The present study revealed statistical difference in the mean values of IgM for patients when compared with IgM of control negative subjects and this shows that IgM antibody to HBV core antigen (IgM anti $\mathrm{HBC}$ ) positivity indicates recent and acute infection with hepatitis $B$ virus in control subjects. IgM is the main immunoglobulin produced early in the primary immune response, IgM is present on the surface of virtually all uncommitted B cells it is the most efficient in defense against bacteria and viruses [33]. Anti HBc IgM is elevated during the acute phase of hepatitis $B$ but will become negative within 6 months, so this may influence the present study that the IgM of positive subjects have started to decline at the time of this study. A study was done on patients with chronic HBV in United Kingdome showed that there was increased spontaneous IgM production due to defect 
Table 6 CD4 and absolute leucocyte counts (Neutrophil, lymphocyte, eosinophil, basophil, monocyte) of male HBAg positive subjects compared with the male HBAg control negative subjects.

\begin{tabular}{|c|c|c|c|c|}
\hline & $\begin{array}{c}\text { HbAg Positive } \\
\text { ( } n=58)\end{array}$ & HbAg Negative $(n=58)$ & t-value & P-value \\
\hline CD4 count (cells/ $\mu \mathrm{L}$ ) & $1130.93 \pm 401.03$ & $1177.24 \pm 359.30$ & -0.654 & 0.516 \\
\hline $\begin{array}{l}\text { Abs. Neut } \\
\left(\times 10^{9} / L\right)\end{array}$ & $2.28 \pm 0.77$ & $2.34 \pm 0.76$ & -0.399 & 0.691 \\
\hline $\begin{array}{c}\text { Abs. Lymph } \\
\left(\times 10^{9} / \mathrm{L}\right)\end{array}$ & $2.27 \pm 0.63$ & $2.13 \pm 0.77$ & 0.997 & 0.323 \\
\hline $\begin{array}{l}\text { Abs. Eosin } \\
\left(\times 10^{9} / L\right)\end{array}$ & $0.10 \pm 0.08$ & $0.16 \pm 0.17$ & -2.083 & $0.042^{*}$ \\
\hline $\begin{array}{l}\text { Abs. Baso } \\
\left(\times 10^{9} / \mathrm{L}\right)\end{array}$ & $0.08 \pm 0.09$ & $0.08 \pm 0.10$ & -0.368 & 0.714 \\
\hline $\begin{array}{c}\text { Abs. Mono } \\
\left(\times 10^{9} / \text { L }\right)\end{array}$ & $0.07 \pm 0.09$ & $0.06 \pm 0.08$ & 0.199 & 0.843 \\
\hline
\end{tabular}

$* \mathrm{P}<0.05$ (Significant)

Table 7 CD4 and absolute leucocyte counts (Neutrophil, lymphocyte, eosinophil, basophil, monocyte) of female HbAg positive subjects compared with the female $\mathrm{HbAg}$ control negative subjects.

\begin{tabular}{|c|c|c|c|c|}
\hline & $\begin{array}{l}\text { HbAg Positive } \\
(n=22)\end{array}$ & HbAg Negative ( $n=22$ ) & t-value & P-value \\
\hline CD4 count (cells $/ \mu \mathrm{L}$ ) & $1020.84 \pm 599.68$ & $1393.77 \pm 349.53$ & -3.456 & $0.001 *$ \\
\hline $\begin{array}{l}\text { Abs. Neut } \\
\left(\times 10^{9} / \text { L) }\right.\end{array}$ & $2.46 \pm 1.49$ & $2.30 \pm 0.73$ & 0.592 & 0.557 \\
\hline $\begin{array}{l}\text { Abs. Lymph } \\
\left(\times 10^{9} / \text { L }\right)\end{array}$ & $1.93 \pm 0.69$ & $2.30 \pm 0.76$ & -2.378 & 0.022 \\
\hline $\begin{array}{l}\text { Abs. Eosin } \\
\left(\times 10^{9} / L\right)\end{array}$ & $0.10 \pm 0.10$ & $0.12 \pm 0.11$ & -0.95 & 0.347 \\
\hline $\begin{array}{l}\text { Abs. Baso } \\
\left(\times 10^{9} / \mathrm{L}\right)\end{array}$ & $0.08 \pm 0.07$ & $0.09 \pm 0.09$ & -0.248 & 0.805 \\
\hline $\begin{array}{l}\text { Abs. Mono } \\
\left(\times 10^{9} / \mathrm{L}\right)\end{array}$ & $0.13 \pm 0.11$ & $0.06 \pm 0.07$ & 3.257 & $0.002^{*}$ \\
\hline
\end{tabular}

${ }^{*} \mathrm{P}<0.05$ (Significant)

Table 8 Haematological parameters of $\mathrm{HbAg}$ positive subjects compared with the $\mathrm{HbAg}$ negative control subjects.

\begin{tabular}{|c|c|c|c|c|}
\hline & $\begin{array}{l}\text { HbAg Positive } \\
\text { (n=102) }\end{array}$ & HbAg Negative ( $n=102$ ) & t-value & P-value \\
\hline $\mathrm{Hb}(\mathrm{g} / \mathrm{dL})$ & $12.0 \pm 1.6$ & $12.4 \pm 1.4$ & -2.032 & $0.045^{*}$ \\
\hline PCV (L/L) & $37.1 \pm 8.7$ & $38.2 \pm 4.7$ & -1.228 & 0.221 \\
\hline WBC $\left(\times 10^{9} / L\right)$ & $5.7 \pm 6.9$ & $4.8 \pm 1.1$ & 1.263 & 0.21 \\
\hline Neut (\%) & $49.8 \pm 10.2$ & $48.3 \pm 10.5$ & 0.965 & 0.337 \\
\hline lymph (\%) & $46.2 \pm 10.1$ & $45.8 \pm 10.8$ & 0.222 & 0.825 \\
\hline Eosin (\%) & $2.2 \pm 1.9$ & $2.9 \pm 2.8$ & -2.107 & $0.038 *$ \\
\hline Baso (\%) & $1.8 \pm 1.6$ & $1.6 \pm 1.7$ & 0.487 & 0.627 \\
\hline Mono (\%) & $2.0 \pm 2.2$ & $1.4 \pm 1.8$ & 2.425 & $0.017^{*}$ \\
\hline
\end{tabular}

* $\mathrm{P}<0.05$ (significant)

in Con A induced suppressor cell function have been identified in association with chronic active hepatitis and a proportion of those with chronic persistence hepatitis, in contrast, patients with acute HBV and minimal liver damage have completely normal profiles [32].

A significant difference was obtained between the mean CD4 count of HBV positive subjects when compared with the mean CD4 count of control negative subjects. This agrees with the fact that in early events of infection Innate immunity generally plays a role immediately after infection to limit the spread of the pathogen and initiate efficient development of an adaptive immune response [34]. Innate responses during the early phase of viral infection are characterized by the production of type 1 interferon (IFN)-\&/B cytokines and the activation of natural killer (NK) cells. The production of type 1 IFNs can be triggered directly by virus replication through cellular mechanisms that detect the 
Table 9 The prevalence of Hepatitis B markers in the positive subjects.

\begin{tabular}{|c|c|c|c|c|}
\hline Serologic markers & Positive(N=150) & \multicolumn{3}{c|}{ Negative(N=102) } \\
\hline HBsAg (N=150) & $\mathbf{N}$ & $\%$ & 18 & 12 \\
\hline HBeAg (N=150) & 132 & 88 & 104 & 69.3 \\
\hline HBsAb (N=150) & 46 & 30.7 & 144 & 96 \\
\hline HBeAb (N=150) & 6 & 4 & 138 & 92 \\
\hline HBCAb (N=150) & 12 & 8 & 130 & 86.7 \\
\hline TOTAL & 20 & 13.3 & 534 & 71.2 \\
\hline
\end{tabular}

$X^{2}=175.380, P=0.000(P<0.05$, significant $)$

Table 10 The prevalence of antibody markers in HBV negative subjects.

\begin{tabular}{|c|c|c|c|c|}
\hline Serologic markers & Positive & \multicolumn{3}{c|}{ Negative } \\
\hline HBsAb (N=102) & N & $\%$ & 58 & 56.9 \\
\hline HBeAb (N=102) & 44 & 43.1 & 38 & 37.3 \\
\hline HBCAb (N=102) & 64 & 62.7 & 46 & 45.1 \\
\hline TOTAL & 56 & 54.9 & 142 & 46.4 \\
\hline
\end{tabular}

$X^{2}=7.989, P=0.018(P<0.05$, significant $)$

presence of viral RNA or DNA [35,36], while NK cells are activated by recognition of stress- induced molecules and the modulation of the quantity of major histocompatibility complex (MHC)-class 1 molecules on the surface of infected cells [37]. It agrees again with the fact that patients who spontaneously recover from HBV infection mount vigorous CD4+ and CD8+ T cells responses to various HBV epitopes. By contrast, patients who develop chronic hepatitis $B$ infection have narrowly focused T-cell response [38].

Significant difference obtained when absolute leucocyte counts (eosinophils and monocytes) of positive subjects were compared with absolute leucocyte counts (eosinophils and monocytes) of control negative subjects $(\mathrm{P}<0.05)$ agrees with work done by Vassilopoulos, et al. [39] that peripheral blood monocytes increase in viral infection while eosinophils have no value in viral infection.

\section{Conclusion}

The result of this study shows the need to include all the serological markers, immunological and haematological parameters in routine diagnosis of HBV infection in Nigeria. It also confirms the fact that testing blood donors for $\mathrm{HBsAg}$ alone is not sufficient to eliminate HBV from blood. Although, the possibility of achieving zero risk of transfusion associated HBV infection depend largely on DNA testing of all the collected units of blood before transfusion; however, since this is not done in many developing countries including Nigeria due to cost, this study recommends the inclusion of all the serological markers ( $\mathrm{HBsAg}, \mathrm{HBeAg}$, anti$\mathrm{HBcAg}, \mathrm{HBsAb}, \mathrm{HBeAb}$ ) in routine screening of blood donors and patients in countries where DNA testing is not done. This will go a long way in reducing Hepatitis B Virus infection. 


\section{References}

1 Nester EW, Anderson DG, Roberts EC, Nester TM (2009) Microbiology a human perspective ( $6^{\text {th }}$ edn) McGraw Hill: NY, USA pp: 606-608.

2 Washington N, Allens S, Konemane JP, Procop OG, Schreckenberger P, et al. (2006) Koneman's Colour Atlas and Textbook of Diagnosis Microbiology ( $5^{\text {th }}$ edn) Lippincoh Williams and Wilkine: Philadelphia, USA pp: 1343-1372.

3 Alter HJ, Blumberg B (1966) Further studies on a new human isopreciptin system. Blood 27: 297-309.

4 Zuckerman AJ (1996) Hepatitis Viruses. In: Baron's Medical Microbiology (4th edn) University of Texas Medical Branch pp: 132-136.

5 Harrison T (2009) Desk Encyclopedia of General Virology. Academic Press: Boston, USA p: 455.

6 http://www.who.int/mediacentre /factsheets/fs204/en/

7 Alberti A, Chemello L, Benvegnu L (1999) Natural history of hepatitis C. Journal of Hepatology 31: 17-24.

8 Barker JF, Silverto RE, Pallister C (1996) Transmission of serum hepatitis. JAMA 276: 841.

9 GanemD,PrinceAM(2004)HepatitisBvirusinfection Natural historyand clinical consequences. N Engl J Med 350: 1118-1129.

10 Lok AS, McMahon BJ (2001) Chronic hepatitis B. Hepatology 34: 1225-1241.

11 Dienstag JI, Isselbacher KJ (2005) Chronic hepatitis ( $16^{\text {th }}$ edn) McGraw Hill: NY, USA pp: 1844-1855.

12 Hoofangle J, Bisceglie A (1991) Serological diagnosis of viral hepatitis. Journal of Hepatology 11: 73.

13 Shikata T, Karasawa T, Abe K, Uzawa T, Suzuki H, et al. (1997) Hepatitis B e antigen and infectivity of hepatitis B virus. J Infect Dis 136: 571-576.

14 http://publications.nice.org.uk/hepatitis-b-chronic-cg165/patientcentred-care.

15 World Health Organization (2001) Introduction of hepatitis B vaccine into childhood. Immunization Services: Geneva, Switzerland.

16 World Health Organisation (1998) No scientific Justification to suspend Hepatitis B Immunization. Public Health Rep 113: 487.

17 Sadoh AE, Eregie CO (2008) Public Health Implications for Hepatitis B Immunization. A textbook of National program on immunization in Nigeria 22: 1318-1320.

18 Odusanya OO (2008) Hepatitis B virus vaccine the Nigeria story IFEMED Journal 14: 4-5.

19 Shi Z, Li X, Ma L, Yang Y (2010) Hepatitis B immunoglobulin injection in pregnancy to interrupt hepatitis $B$ virus mother-to-child transmission a meta-analysis. International Journal of infectious Diseases 14: 622-634.

20 Li XM, Yang YB, Hou HY, Shi ZJ, Shen HM, et al. (2003) Interruption of HBV intrauterine transmission, a clinical study. World Journ of Gastroenterol 9: 1501-1503.

21 http://www.nigeriavillagesquare.com/.../npc-releases-2006population-figures-14.

22 Forbi JC, Vaughan G, Purdy MA, Camp DX, Xia GL, et al. (2010)
Epidemic History and Evolutionary Dynamics of Hepatitis B infection in Two Remote Communities in Rural Nigeria. PLOS One 5: e11615.

23 Ola SO, Anomneze EE, Chukwuma CM, Ojo OS, Ndububa DA, et al. (2000) Interferon alpha-2a (Roferon-A) in the management of chronic Hepatitis $B$ infection. Result of an open prospective study in Nigerian patients. West Afri Med J 19: 259-264.

24 Ola SO, Otegbayo JA, Odaibo GN, Olaleye OD, Olubuyide IO (2002) Serum Hepatitis C Virus and Hepatitis B surface Antigenaemia in Nigerian patients with acute icteric hepatitis. West Afri J Med 21: 251-257.

25 Ola SO, Otegbayo JA, Odaibo GN, Olaleye DO, Olubuyide IO, et al. (2009) Occult HBV infection among Nigerian Adults. J Infect Dev Ctries 3: 442-446.

26 Van Ditzhuijsen TJ, Selten GC, Van Loom AM, Wolters G, Matthyssen $L$, et al. (1985) Detection of Hepatitis B DNA in serum and relation with the IgM class anti-HBC titres in Hepatitis B infection. J Med Virol 15: 49-56.

27 Fasola FA, Otegboyo JA, Abijah UMA, Ola SO (2009) Haematological parameters in Nigerians with acute viral hepatitis. 1: 1 27-31.

28 Connard ME, Schwartz FO, Young AE (1965) Viral Hepatitis in Korea: Clinical observations and studies performed during prospective studies to obtain specimens for virologic culture. 2: 395-415.

29 Vingerhoets J, Michielsen G, Vanham E, Bosmans E (2000) HBVspecific lymphoproliferative and cytokine responses in patients with chronic hepatitis B. J Hepatol 33: 169.

30 Zuberi S, Siddiqui M, Lodi T (1997) Immunoglobulin in liver disease. J pak Med Assoc 27: 391-392.

31 Craig JI, Haynes AP, Mcclelland DB, Ludlam CA (2002) Blood disorders in viral diseases. Annu Rev Med 53: 15-33.

32 Kayhan TA, Nouri GJ, Alexander J, Portmann B (1986) In vitro study of IgG production and concanavalin $A$ induced suppressor cell function in acute and chronic hepatitis B infection. Clin Exp Immunol 64: 50-58.

33 Geo BJ, Butel JS, Carroll KC, Morse SA (2007) Medical microbiology (24th edn.) Mc Graw Hill: NY, USA pp: 398-399.

34 Fisicaro P, Valdatta C, Massari M, Mori C, Zerbini A, et al. (2009) Early kinetics of innate and adaptive immune response during hepatitis $B$ virus infection. Gut 58: 974-982.

35 Alexopoulon L, Hon A, Medzhitov R, Flavell R (2001) Recognition of double stranded RNA and activation of NF-KB by Toll-like receptors. Nature 413: 732-738.

36 Heil $\mathrm{F}$, Hemmi $\mathrm{H}$, Hochrein $\mathrm{H}$, Ampenberger $\mathrm{F}$, Kirschning $\mathrm{C}$, et al. (2004) Species-specific recognition of single- stranded RNA via tolllike receptor-7 and 8. Science 303: 1526-1529.

37 Moretta L, Bottino C, Pende D, Vitale M, Mingari M, et al. (2005) Human natural killer cells, molecular mechanisms controlling NK cell activation and tumor cell lysis. Immunol let 100: 7-13.

38 Rehermann B, Nascimbeni M (2005) Immunology of hepatitis B virus and hepatitis $C$ virus infection. Immunology 5: 215-229.

39 Vassilopoulos D, Rapti I, Nikolaou M, SJ Hadziyannis J (2008) Cellular immune responses in hepatitis $B$ virus e antigen negative chronic hepatitis B. J Viral Hepat 14: 352-357. 